\title{
Az élelmiszer-termelés relokalizációjának térbeli különbségei és változásuk Magyarországon a XXI. század elején
}

\section{Spatial differences and their changes in the relocalisation of food production in Hungary at the beginning of the 21st century}

\author{
INZSÖL RENÁTA
}

INZSÖL Renáta: PhD-hallgató, Soproni Egyetem, Lámfalussy Sándor Közgazdaságtudományi Kar, Széchenyi István Doktori Iskola; 9400 Sopron, Erzsébet u. 9.; inzsol.renata.orsolya@phd.uni-sopron.hu; https://orcid.org/0000-0002-0903-1271

KULCSSZAVAK: rövid ellátási lánc; helyi élelmiszerrendszer; vidékfejlesztés

ABSZTRAKT: A helyi élelmiszer-termelés felértékelődése egyaránt jellemző az Európai Unióban és Magyarországon. A fejlesztési források területileg leghatékonyabb elosztásához a szakpolitikai döntéshozatal számára elengedhetetlen egy olyan eszköz, mely az élelmiszerelőállítás térbeli adottságait és fejlődési lehetőségeit is figyelembe veszi. A 2014-2020-as programozási időszak kezdetén nemzetközi minta alapján a hazai viszonyokra adaptált és meghatározott élelmiszer-relokalizációs index éppen ezt a célt szolgálta. Az időszak végéhez közeledve aktuális a változások vizsgálata. Az elmúlt öt évre vonatkozóan a tanulmány értékeli a hazai élelmiszer-relokalizációs termelői index változását, mely alkalmas a termelői adottságok és a fejlődési potenciál megyénkénti elemzésére. Mivel a korábbi indexben használt indikátorok nem mindegyike releváns, illetve a súlypontok áthelyeződtek, így a korábbi index módosított összetétellel került kiszámításra. Az eredmények azt mutatják, hogy a korábbi, 2014-es kutatáshoz hasonlóan a hagyományosan mezőgazdasági jellegü megyék esetében hasznosulhatnak leggyorsabban a hazai és EU-s támogatások. Míg az egyéni gazdaságok száma rohamosan csökkent, a 2000-es évek elejétől az ötödére esett vissza, addig a kistermelői aktivitási szint - amely több tényezővel is jellemezhető, mint a védjegyek vagy a termelői piacok száma - kilenc megyében nőtt 2014-ről 2019-re. Az elmúlt öt évben ugyan jelentős fejlődés ment végbe a helyi élelmiszer-termelésben és -értékesítésben, a lehetőségek még korántsem kiaknázottak teljes mértékben.

Renáta INZSÖL: PhD student, István Széchenyi Doctoral School, Alexandre Lámfalussy Faculty of Economics, University of Sopron; Erzsébet u. 9., H-9400, Sopron, Hungary; inzsol.renata.orsolya@phd.uni-sopron.hu; https://orcid.org/0000-0002-0903-1271

KEYWORDS: short food supply chain; local food system; rural development

ABSTRACT: The valorisation of local food production has gained momentum both in the European Union and Hungary over the past decade. The Common Agricultural Policy treats the shortening of the food supply chain and the reduction of distance between producers and consumers as a special goal. The paper tries to provide a tool for the most efficient spatial distribution of available rural development sources, which also considers the spatial characteristics of food production. The Index of Food Relocalization adapted at the beginning of the 2014-2020 EU programming period and defined for Hungarian conditions served this purpose. The index originally consisted of two main parts: a producer sub-Index and a marketing sub-Index, from which only the producer sub-Index was elaborated in the Hungarian context.

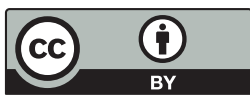


As the end of the programming period is approaching and it is important to investigate changes in the activity of small-scale farmers between 2014 and 2019. The paper evaluates the changes of the domestic producer sub-Index of Food Relocalization related to the past 5 years. The sub-Index shows differences in the spatial distribution and development possibilities of local food systems. Calculations were made for Budapest, the capital, and the 19 counties of Hungary. Since not all indicators of the previous sub-Index are relevant for this research the producer sub-Index was calculated with modified indicators. Several new homepages and databases - even webshops - presenting local producers have been created in the past years. These usually have a smaller regional coverage, and they do not give proper information about the difference of farmers' activities at county level. Because of these changes the number of farmers' markets indicator was involved in the analysis instead of the number of producers advertising in online databases. It is mainly the local government and the civil sector that play a crucial role in establishing farmers' markets. This provides a broader perspective onto the range of regional development of short food supply chains.

The results show that similar to previous research from the year 2014, Hungarian and EU subsidies could become useful in traditionally agriculture-dominated counties. While the number of individual farmers has continuously been declining from the beginning of the first decade of the 21st century, the level of small-scale farmer activity has increased in 9 counties from 2014 to 2019. Great growth in the number of local product trademarks, relevant databases, webshops and even farmers' markets have led to a remarkable development in the local food movement. Overall, the results show still largely unexploited potential for development in Hungarian short food supply chains. The analysis of the marketing side of the index could be the subject of a further study, which could give an overview of the present situation of food relocalization in Hungary.

\section{Bevezetés}

A régmúltban a legtöbb élelmiszert helyben állították elö, és helyben is fogyasztották. A nemzetközi kereskedelem térhódításával és a fogyasztói társadalom kialakulásával egy időben az élelmiszer-ellátás is globálissá vált. Az üzletek polcain az év minden időszakában megtalálhatóak a világ bármely pontjáról érkező élelmiszerek. Az élelmiszeripar gyakorlatilag elszakadt a helyi mezőgazdaság adta lehetőségektől (Ilbery, Kneafsey, Bamford 2000), és néhány világméretű nagyvállalat uralma alá került (Howard 2009). Az elmúlt évtizedek élelmiszerbotrányai megrengették a fogyasztók bizalmát a globális élelmiszerekben (Forbes et al. 2009; Toler et al. 2009). Renting, Marsden és Banks (2003) azt állítják, hogy az ellátási lánc rövidítése lehetőséget ad a termék igazi értékének és földrajzi eredetének tisztázására azáltal, hogy minimalizáljuk a közvetítők számát az elő́llításban, a feldolgozásban, az elosztásban és az értékesítésben.

A szakirodalom a „helyi”, a rövid élelmiszer-ellátási lánc, illetve a közvetlen értékesítés fogalmát többféle szempontból határozza meg. Gyakran ezen kifejezések szinonimaként szerepelnek. Kneafsey és szerzőtársai (2013) definiálták a rövid ellátási lánc fogalmát, miszerint a termelő és fogyasztó között megjelenő szereplők száma minimális, ideális esetben nulla. A téma más kutatói is a termelők és a fogyasztók közötti szoros földrajzi és így személyes, már-már bizalmi kapcsolatra helyezik a hangsúlyt (Marsden 2000; Martinez et al. 2010; Murdoch, Marsden, Banks 2000; Renting, Marsden, Banks 2003; Smithers, Lamarche, Joseph 
2008; Sonnino 2007). A termelő és a fogyasztó közötti földrajzi távolság az egyes országokban nagyon eltéro", mely egyaránt függ az ország területének nagyságától és a jogszabályi feltételektől. Az USA-ban például az értékesítés helyétől számított 400 mérföld, azaz megközelítőleg 644 km, vagy az adott állam területe az a távolság, amelyen belül az élelmiszer helyinek számít (Martinez et al. 2010). Kanadában ez csupán 31 mérföld, vagyis körülbelül 50 km (inspection.gc.ca 2019). Az Európai Unióban nincs egységes gyakorlat a helyi élelmiszer földrajzi határának megállapítására, országonként eltérő, általában 20 és 100 km között változik. A hazai jogszabályi meghatározás 40 km-es körzetben vagy a megyehatáron belül jelölte ki a rövid ellátási láncok, helyi termékek piacát, kivétel ez alól a fóváros, ahová az egész országból szállíthatók a helyi élelmiszerek (52/2010. (IV. 30.) FVM rendelet a kistermelői élelmiszer-termelés, -előállítás és -értékesítés feltételeiről). Mindezektől függetlenül elsősorban a fogyasztó az, aki eldönti, hogy az adott terméket helyinek tekinti-e vagy sem (European Commission 2006). Egyes kutatások szerint a fogyasztók hajlandók magasabb árat fizetni a helyi termékekért a velük járó élmény és a bizalmi attitűd miatt (Burton 2001; Van Wezemael et al. 2014). Az élelmiszer-biztonság csökkenésével egyre nagyobb figyelem irányul a helyi védjegyekre és az eredetmegjelölésre (Caputo et al. 2013). A „helyi” segíti a rendszerben való gondolkodást, továbbá lehetőséget kínál a választásra (Hendrickson, Heffernan 2002). Nem kell elfogadnunk a konvencionálist, a tömegterméket, s továbbmenve, a kapitalista ideológiát sem, hanem a magunk urai lehetünk a globalizálódó világban (Robinson, Farmer 2017).

Az ezredforduló után az Európai Unió mezőgazdaságában és regionális politikájában, de a világ más térségeiben is egyre nagyobb figyelmet kapott a helyi élelmiszer-termelés (Kiss 2005; Robinson, Farmer 2017). Hazánkban is a fogyasztói és így a szakpolitikai érdeklődés középpontjába került. Ricketts Hein, Ilbery és Kneafsey (2006) arra hívják fel a figyelmet, hogy a helyi élelmiszerrendszer egy adott ország különböző régióiban eltérő adottságokkal rendelkezhet. Téves következtetésekhez vezethet, ha figyelmen kívül hagyjuk az eltéréseket. Az élelmiszer-relokalizáció szakpolitikai stratégiaként fogalmazódott meg az élelmiszerlánc fenntarthatóságának elősegítése, és a globális ellátási lánc hátulütőinek csökkentése érdekében (Hinrichs 2003). Egyes kutatók azonban kételkednek a lokális ellátási lánc fenntarthatóságában a globálissal szemben (Lamine 2015; Schader et al. 2014). Az élelmiszer relokalizáció elsőként a jóléti társadalmakban indult el, mint az Amerikai Egyesült Államokban vagy az Európai Unió országaiban (Kneafsey et al. 2013; Martinez, 2010).

Tanulmányomban célom az eredetileg Ricketts Hein, Ilbery és Kneafsey (2006) által létrehozott, a Benedek és Balázs szerzőpáros (2014) által hazai viszonyokra adaptált élelmiszer-relokalizációs termelói index újraszámolása, továbbá a helyi élelmiszerrendszerek térbeli mintázatának ismételt meghatározása és az eltérések elemzése. 
Az index újraszámolását azért tartom időszerünek, mert a hazai viszonyok elemzése óta eltelt öt évben számos fejlesztés valósult meg ezen a területen. A hazai Vidékfejlesztési Programban (2014-2020) külön alprogramként jelenik meg a rövid ellátási lánc. Fejlesztésére közvetlenül három felhívás irányul, melyek esetében összesen 17,98 milliárd forint a rendelkezésre álló keretösszeg (palyazat.gov.hu/node/56582\# 2019). A „VP3-4.2.1-4.2.2-19 A Rövid Ellátási Lánchoz kapcsolódó beruházások támogatása az élelmiszeripar és a borászat területén" felhívás 2019 december elején jelent meg, amelyre 2019 végéig még nem nyújtottak be igénylést. A „VP6-7.2.1-7.4.1.3-17 Helyi termékértékesítést szolgáló piacok infrastrukturális fejlesztése, közétkeztetés fejlesztése" felhívás 2017 februárjában jelent meg, és a tavalyi év végéig 453 pályázat esetében kötöttek szerződést 35374 706,80 euró támogatási összegben. A "VP3-16.4.1-17 Együttműködések támogatása a REL és a helyi piacok kialakításáért, fejlesztéséért és promóciójáért" felhívás 2017. március végén jelent meg, eddig összesen 11 pályázat részesült támogatásban 2364 199,37 euro értékben.

Jelen tanulmányban a 2014-ben hazai viszonyokra adaptált index indikátorait felülvizsgáltam és módosítottam, majd ezen adatokkal számoltam újra az index értékeit. A tanulmányban a következő hipotéziseket vizsgáltam:

- H1: A kistermelői aktivitási szint nőtt Magyarországon 2014 és 2019 között.

- H2: A támogatások azokba a megyékbe érkeznek, ahol felhasználásuk a leghatékonyabb.

\section{A magyar agrárgazdaság területi jellemzői}

A magyar agrárgazdaságban tevékenykedő gazdaságok száma az ezredforduló óta folyamatosan csökken. Míg 2000-ben mintegy 965 ezer gazdaság végzett mezőgazdasági tevékenységet, 2016-ra számuk ennek 45 százalékára, közel 431 ezerre esett vissza (A magyar mezőgazdaság regionális különbségei 2016). Érdekes azonban, hogy ezen belül a gazdasági szervezetek száma lassú ütemben növekedett, míg az egyéni gazdaságok száma rohamosan csökkent, a 2000-es évek elejétől az ötödére esett vissza. Az egyéni gazdaságok számának csökkenése mögött meghúzódó ok az ágazatban tapasztalható elöregedés, a fiatalok elvándorlása a vidéki térségekből, illetve egyéb ágazatokban történő elhelyezkedése, melyhez valószínűleg a bruttó átlagkeresetek növekedése is hozzájárult. 2014-ről 2018-ra közel 40 százalékkal emelkedtek a bruttó átlagkeresetek, mely sok gazdálkodó esetében elég motiváló tényező volt ahhoz, hogy feladja - gyakran az időjárás viszontagságainak kitett - mezőgazdasági tevékenységét, és elhelyezkedjen egy havonta fix bért kínáló állásban. Az idősebb - főleg 65 év feletti - gazdálkodók közül sokan hagytak fel a termeléssel. „2016-ban az egyéni gazdaságok jelentős része, csaknem fele az Alföldön gazdálkodott. Számuk minden megyében csökkent 2010-hez képest, legjelentősebben Budapesten, valamint Pest, Veszprém, Borsod-Abaúj- 
Zemplén megyékben. Ezekben a megyékben közel harmadával kevesebben foglalkoznak mezőgazdasággal, mint hat évvel korábban. Az egyéni gazdaságok számának csökkenése legkevésbé a Dél-Dunántúlon és az Alföldön érezhetö, főként Tolna és Hajdú-Bihar megyék stabilabb gazdaságszáma miatt. Itt szorult vissza legkevésbé a 45 év feletti gazdálkodók aránya is, ugyanakkor a legfiatalabb generáció részaránya átlagon felül csökkent" (KSH 2016, 5.). A KSH adatai (2016) alapján a csökkenés leginkább azokat az egyéni gazdaságokat érintette, amelyek 1 hektár alatti területen gazdálkodtak, számuk 43 százalékkal csökkent 2010-hez képest. Ez a birtokméret a leginkább jellemző a kistermelői termék-előállításra (Hamza, Tóth 2006).

A KSH (2019) adatai alapján a művelési ágak szerint is láthatunk megyei szintű különbségeket. 2019-ben a szántóföldi növénytermesztés Békés megyében volt a legjelentősebb. Itt található az ország szántóterületeinek 9,5 százaléka, 409 ezer hektár. Az ország legnagyobb szőlőterületét Bács-Kiskun megye tudhatja magáénak (21 200 hektár), a gyümölcsösök 31,9 százaléka pedig Szabolcs-Szatmár-Bereg megyében van. Az országban az egyéni gazdaságok használatában van a szőlőterületek 77 százaléka, illetve a gyümölcsösök 75 százaléka, valamint értelemszerüen a konyhakertek csaknem 100 százaléka.

Az állatállomány, mely a szarvasmarhát, a sertést, a juhot és a tyúkot foglalja magában, jelen adatok alapján, országos szinten 2010-ről 2019-re 3,6 százalékkal csökkent. A legmagasabb állatállománnyal rendelkező megye 2019-ben Hajdú-Bihar megye volt (5 $744900 \mathrm{db}$ ), majd követte Bács-Kiskun megye (3 $844600 \mathrm{db}$ ) és Budapest (3 $023100 \mathrm{db}$ ). Az állatállomány számában a legnagyobb növekedés Budapest esetében látható, ahol 480,3 százalékkal nőtt 2010-ről 2019-re; nagyarányú növekedés főként a sertések és tyúkok számában tapasztalható. Kisebb mértékủ növekedés látható Zala, Heves és Pest megyékben. Ezzel ellentétben hatalmasat esett az állatállomány Komárom-Esztergom megyében (57,3 százalékkal), amely a tyúkok számának csökkenésére vezethető vissza. Jelentősebb csökkenés figyelhető meg Somogy, Baranya, Szabolcs-Szatmár-Bereg és Borsod-Abaúj-Zemplén megyékben is.

\section{Adatok és módszerek}

A tanulmány bemutatja az élelmiszer-relokalizációs termelői index összetevőit és számítási módszertanát. Ezt követi az eredmények értékelése és a jövőbeni szakpolitikai hasznosíthatóság elemzése.

Az élelmiszer-relokalizációs index alapjául Knox (1974) Angliában és Walesben készített életszínvonal-számításai szolgáltak. Ugyanezt a számítást alkalmazta Ilbery (1984) a társadalmi jólét komparatív szintjének elemzésére Európában. Ezen számítási módszertant használta fel Ricketts Hein, Ilbery és Kneafsey (2006) a helyi élelmiszerrendszerek térbeli jellegzetességeinek feltárására. Az index az élelmiszer-relokalizációs index (Index of Food Relocalization) nevet 
1. táblázat: Az élelmiszer-relokalizációs termelői index kiszámításához használt indikátorok a korábbi és jelen tanulmány alapján

Indicators used in calculating the Index of Food Relocalization Producer sub-Index on the basis of the previous and the present study Az élelmiszer-relokalizációs termelói index Benedek Az élelmiszer-relokalizációs termelói index jelen és Balázs (2014) által használt indikátorai tanulmányban használt indikátorai

1. A biogazdálkodók száma (2013)

2. Helyi élelmiszer adatbázisban hirdető helyi termelők száma (2013)

3. A kistermelők száma (2011)

4. A védjegyek száma (2013)

5. Értékesítésre termelő egyéni gazdaságok száma (2010) 1b. A biogazdálkodók száma (2019)

2b. A helyi termelői piacok száma (2019)

3b. A kistermelők száma (2017)

4b. A védjegyek száma (2019)

5b. Részben vagy egészben értékesítésre termelő egyéni gazdaságok száma (2016)

Forrás: Benedek, Balázs (2014) és saját adatgyüjtés alapján a szerző szerkesztése

kapta. Eredetileg két fő részből, a termelői és értékesítési indexből állt, de hazai viszonyokra csak a termelői index esetében adaptálta Benedek és Balázs (2014). Jelen tanulmány is kizárólag a termelői indexet vizsgálja. A vizsgált élelmiszerrelokalizációs termelői index (ÉRTI) a helyi élelmiszerrendszerek térbeli elterjedtségének és fejlődési lehetőségeinek különbségeit mutatja.

Az élelmiszer-relokalizációs termelői index kiszámításához használt öt indikátor részletesen:

1-1b. A biogazdálkodók száma. Az adatok a Benedek és Balázs szerzőpáros 2014-ben megjelent tanulmányához hasonlóan, a két hazai minősítő szervezet (Biokontroll Hungária Nonprofit Kft. - HU-ÖKO-01 - és Hungária ÖkoGarancia Kft. - HU-ÖKO-02) honlapjáról származnak. HU-ÖKO-01 esetében 2017. májusi adatok álltak rendelkezésre, a HU-ÖKO-02 minősítő rendszerhez viszont friss, 2019. májusi értékek szolgáltak alapul. Az eredeti adatok 2013-ra vonatkoztak.

2-2b. Helyi élelmiszer adatbázisban hirdető helyi termelök száma / A helyi termelói piacok száma. Az eredeti forrás, a Termelőtől.hu Kft. honlapja nem került bele a vizsgálatba. 2013 augusztusában csaknem 12500 gazdálkodó adatait tartalmazta az adatbázis, viszont a 2019 májusi adatgyüjtés alapján csak 1109 termelő hirdetett a felületen. Az elmúlt években számos új, a helyi termelőket bemutató, esetlegesen rendelési lehetőséget is nyújtó honlap, adatbázis jött létre. Ezek elsősorban kisebb hatókörűek, országos lefedettséggel rendelkező csak egy-kettő akad, ám még ezek sem tudhatnak maguknak egy-két ezernél több hirdetőt. Az online felületekhez történő csatlakozás már nem jelent akkora kuriózumot, mint korábban, és sok termelő rendelkezik saját honlappal vagy közösségi oldallal. Az eredeti, Ricketts Hein, Ilbery és Kneafsey (2006) által készített, angol és walesi helyzetet feltáró tanulmány tartalmaz egy ún. marketing alindexet is, melynek része a „termelői piacok száma” indikátor. Jelen tanulmányban a „Helyi élelmiszer adatbázisban hirdető helyi termelők száma” indikátor helyett „A helyi ter- 
melői piacok száma" indikátort használva (2019. júliusi gyűjtés) is kiszámoltam az indexet. Az adatok a Nemzeti Agrárgazdasági Kamara „Termelői piac kereső” alkalmazásából (nak.hu 2019) származnak. A módosított indikátorral számolt index értékeit „,b” jel jelöli a mutatók évszáma mellett. Azért döntöttem az indikátor cseréje mellett, mert 2014-ben, amikor az eredeti magyar felmérés készült, még nem volt jelentős a termelői piacok száma. Az e piacok működését szabályozó rendelet (51/2012. (VI. 8.) VM rendelet a helyi termelői piacokon történő árusítás élelmiszer-biztonsági feltételeiről) is csak 2012-ben jelent meg. Mára azonban az országban már egyre több helyen találkozhatunk a kis- és őstermelőknek értékesítési lehetőséget nyújtó piacokkal. Az indikátor alkalmas a civil és önkormányzati szféra aktivitásának bemutatására is, hiszen jellemzően ők járnak élen a helyi termelői piacok megnyitásában és működtetésében. A helyi termelői piac a rövid ellátási láncok egyik legegyszerűbb értékesítési módja, mely már megkövetel egy bizonyos fokú hálózatba szerveződő együttműködést is a résztvevők között.

3-3b. A kistermelók száma. Az elemzésben az Országos Területfejlesztési és Területrendezési Információs Rendszer (TeIR) legfrissebb, 2017-re vonatkozó adatai szerepelnek. A korábbi tanulmány 2011-es adatokkal számolt.

4-4b. A védjegyek száma. A Szellemi Tulajdon Nemzeti Hivatala honlapjáról gyűjtöttem ki az adatokat 2019 márciusában. A keresést az eredeti tanulmány 2013 augusztusára vonatkozó adataihoz képest bővítettem. Az elemzésbe az eredetileg csak a „helyi” megnevezésre vonatkozó keresésen túl bevontam a „termék” és a "vidék" kulcsszavakat is. Ugyancsak kizártam azokat a védjegyeket, melyek esetében magánszemélyek vagy viszonteladók a védjegyjogosultak. Az országos lefedettséggel rendelkező védjegyeket nem vettem figyelembe a helyi jelleg biztosítása érdekében.

5-5b. Értékesitésre termelő egyéni gazdaságok száma / Részben vagy egészben értékesitésre termelo" egyéni gazdaságok száma. Itt bővítettem a keresést, hiszen az eredeti tanulmányban kizárólag csak értékesítésre termelő egyéni gazdaságok szerepeltek az általános mezőgazdasági összeírás 2010-es adatai alapján. A KSH adatgyüijtése azonban jelenleg csak a fenti kategóriára vonatkozik, s ebből is csak a 2016-os adat állt rendelkezésre.

Az általam használt számítási módszer mindenben megegyezik Benedek és Balázs 2014-es tanulmányában alkalmazott módszerrel. Az élelmiszer-relokalizációs termelői index számításának képlete Benedek és Balázs (2014) alapján:

$$
\text { ÉRTIji = } 100 \mathrm{Ri} / \mathrm{NM} \text {, }
$$

„ahol ÉRTIji az i-edik megye jelenlegi termelési aktivitásra vonatkozó élelmiszer-relokalizációs termelői indexe, $R i$ az egyes indikátorok rangsorszámainak összege i-edik megyében, $N$ az egyedi változók száma (ami jelen esetben 5), $M$ a megyék száma (összesen $20 \mathrm{db}$ ).

Az index elvi szélsőértékei: 5 (ha egy megye minden változó esetében első) és 100 (ha egy megye minden változó esetében huszadik)" (Benedek, Balázs 2014, 68.). Az elemzésben nem az abszolút számok szerepelnek, hanem az egyes me- 
gyéknek az adott indikátor tekintetében elfoglalt helye a rangsorban. Az alacsonyabb érték jelenti a jobb teljesítményt, hiszen így az adott megye minden indikátor tekintetében előrébb szerepel a rangsorban. Azonos értékek esetén a megyék ugyanazon rangsorszámot kapják, így a sorrendben következő megye rangsorszáma annyival magasabb lesz, ahány megegyező érték szerepelt a táblázatban. Tehát, ha a biogazdálkodók száma két megyében is 47 , akkor mindkét megye a 11-es rangsorszámot kapja, de a következő megye már a 13. lesz a listában. A fenti indikátorok alapján képzett élelmiszer-relokalizációs index alkalmas arra, hogy feltárja megyei szinten a helyi élelmiszerrendszer kínálati oldalát, vagyis azt, hogy hány gazdálkodó látja el a piacot, vannak-e biotermelők, mennyire aktívak a gazdákat segítő civil szervezetek.

A jelenlegi helyzet feltárásán túl fontos látni, hogy milyen mértékű fejlődési potenciállal rendelkezik a vizsgált terület. A helyi élelmiszerrendszer fejlődési potenciálja, vagyis ÉRTI $\mathrm{pi}_{\mathrm{i}}$ étékei azt mutatják, hogy az i-edik megyében a helyi élelmiszerrendszerben milyen fejlődési lehetőségek rejlenek. Mennyire érdemes állami, EU-s forrásokat vagy civil erőfeszítéseket az adott terület fejlesztésébe fektetni. Az indikátorok értékeit ebben az esetben a társas és egyéni gazdaságok számához (KSH 2016) viszonyítottam. Kivétel ez alól a helyi termelői piacok és a védjegyek száma, mivel ezek nagyságát nem annyira a termelők száma, mint inkább a civil és önkormányzati aktivitás határozza meg. A módszertant tekintve ebben az esetben is követtem a korábbi cikk gyakorlatát.

Ezután ÉRTI ${ }_{\mathrm{ji}}$ és ÉRTI $\mathrm{pi}_{\mathrm{i}}$ étékeit összehasonlítottam egymással, illetve figyelembe vettem a mezőgazdasági területek arányát (TeIR 2016) is. Az elemzés során, a 2014-es elemzéshez hasonlóan, fizikai korlátozó tényezőként a nem mezőgazdasági területek arányát i-edik megyében $\left(\mathrm{NMTA}_{\mathrm{i}}\right)$ is vizsgáltam. Az ÉRTI ${ }_{\mathrm{ji}}$ és ÉRTI ${ }_{\mathrm{pi}}$ esetében az alacsonyabb érték nagyobb teljesítményt mutat, tehát annak érdekében, hogy ugyanolyan skálán kapjuk meg az értékeket, a rendelkezésre álló mezőgazdasági területek helyett a nem mezőgazdasági területek arányát szükséges bevonni a számításokba.

Hazánkban, Nyugat-Európához vagy az USA-hoz viszonyítva, jelenleg még alacsony fejlettségi szinten állnak a helyi élelmiszerrendszerek. Legelterjedtebb csatornái a hagyományos és termelői piacok (Szabó 2017). Azon megyékbe érdemes eljuttatni a hazai és EU-s támogatásokat, ahol a leghatékonyabban hasznosulhatnak. Ott várható a leggyorsabb fejlődés, ahol nagyobb számban vannak jelen a helyi gazdálkodók, vannak még a mezőgazdasági tevékenységbe bevonható területek, támogató és nyitott a civil és önkormányzati szféra. A támogatások optimális allokációját i-edik megyében $\mathrm{OA}_{\mathrm{i}}$ mutatja, melynek képlete:

$$
\mathrm{OA}_{\mathrm{i}}=\text { ÉRTIji }+ \text { ÉRTI }_{\mathrm{pi}}+\mathrm{NMTA}_{\mathrm{i}}
$$

$\mathrm{OA}_{\mathrm{i}}$ értéke annál kedvezőbb, minél alacsonyabb, hiszen az adott megyében megfelelő számban vannak jelen a helyi gazdálkodók, aktív a civil szféra, a szereplők társas és egyéni gazdaságokhoz viszonyított aránya fejlődési potenciált rejt, továbbá a még bevonható mezőgazdasági területek nem korlátozzák a termelés növelését. 


\section{Az eredmények értékelése}

Az ÉRT $\mathrm{Ij}_{\mathrm{Ij}}$, vagyis az élelmiszer-relokalizációs termelői index jelenlegi értékei azt mutatják, hogy a kistermelői aktivitási szint megyénként az egyes indikátorok tekintetében nagyon eltérő, ahogy ez a 2014-es kutatás idején is jellemző volt. Az összehasonlítás miatt szerepeltetem a 2014-es kutatás eredményeit is, ahogy ezt a többi mutató esetében is megtettem (2. táblázat, 1-2. ábra).

Budapesten ugyan értelemszerủen alacsony a kistermelők száma, a közülük biogazdálkodást folytatók száma kiemelkedően magas, illetve sok termelői piac létesült az elmúlt években. Az ÉRTI értéke Szabolcs-Szatmár-Bereg, Bács-Kiskun, majd Hajdú-Bihar és Borsod-Abaúj-Zemplén megyékben a legalacsonyabb (19, 26 és 30-30), vagyis itt a legnagyobb a kistermelői aktivitási szint. Hajdú-Bihar megye csupán a termelői piacok számát tekintve került a középmezőnybe, de a többi indikátor esetében az élmezőnybe tartozik. Borsod-Abaúj-Zemplén megyében inkább az értékesítési oldal erős. A megyében ugyan kiemelkedő a védjegyek száma, viszont a bejegyzett hat közül négynek ugyanazon LEADER csoport a jogosultja. Magas az adatbázisban hirdetők száma is, de a gazdálkodók száma inkább a középmezőny értékeihez közelít. Borsod-Abaúj-Zemplén megye jól áll a helyi termelői piacok számát tekintve, a 2014-es 7. helyről feljött a 3. helyre.

2014-hez képest 9 megyében csökkent ÉRTI ${ }_{j}$ értéke, vagyis nőtt a kistermelői aktivitási szint. Tolna és Hajdú-Bihar megyékben nem változott ÉRTI ${ }_{j}$ értéke. Szabolcs-Szatmár-Bereg és Bács-Kiskun megyék továbbra is a legaktívabbak, pontszámuk is csökkent, fóként Szabolcs-Szatmár-Beregben nagyobb a csökkenés mértéke (Szabolcs-Szatmár-Bereg megyében 27-ről 19-re, Bács-Kiskun megyében 28-ról 26-re csökkent), amely a többi megyéhez viszonyítva a kistermelői aktivitási szint relatív növekedését jelenti.

Egy kicsit átrendeződött a középmezőny 2014-hez viszonyítva, hiszen Veszprém és Tolna megyék bekerültek az első tíz helyezett közé, Baranya és Jász-Nagykun-Szolnok megyék viszont kikerültek onnan. Komárom-Esztergom megye a legutolsó helyről előbbre került, a 17. helyre. Az elmúlt öt évben a legnagyobb visszaesést a kistermelői aktivitási szintet tekintve Heves megye produkálta, a 11. helyről visszacsúszott a 18. helyre, ami nagyrészt az értékesítésre termelő gazdálkodók és a biogazdálkodók számának relatív csökkenésére vezethető vissza.

Az ÉRTI ${ }_{p}$ értéke mindkét évben számolva Budapest esetében a legkedvezőbb, ami annak köszönhetö, hogy a fóváros rendelkezik a legnagyobb felvevőpiaccal, továbbá a jogszabályi keretek is lehetővé teszik, hogy bármely kistermelő itt értékesítsen. Győr-Moson-Sopron megye helyzete hasonló Budapestéhez, hiszen itt is nagy a fizetőképes kereslet, földrajzi fekvéséből adódóan magas a kistermelői aktivitás és kiemelkedő a biogazdálkodók száma is. Tizenkét esetben csökkent a mutató értéke 2014-ről 2019-re. Érdekes, hogy ÉRTIj alapján első helyen álló Szabolcs-Szatmár-Bereg megye esetében a fejlődési potenciál nem olyan számottevő, tehát az elkövetkezendő években várható, hogy a többi megye utoléri vagy 
2. táblázat: A helyi élelmiszerrendszer szereplőinek megyei aktivitási szintje (ÉRTI $)$ 2014, 2019

Level of activity of local food system stakeholders on a county basis (ÉRTI.) 2014, 2019

inegye, blogazaalko- Helyltermelol Kıstermelok A veajegyek Keszben vagy tKII] LKII] Megnevezés dók piacok egészben 201420196 értékesitésre termelő egyéni gazdaságok

Száma Rang- Száma Rang- Száma Rang- Száma Rang- Száma Rang-

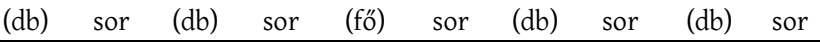

\begin{tabular}{|c|c|c|c|c|c|c|c|c|c|c|c|c|}
\hline & (ao) & sor & (av) & sor & (10) & sor & (ao) & sor & (ab) & sor & & \\
\hline Szabolcs- & 92 & 3 & 20 & 6 & 2245 & 4 & 2 & 5 & 27596 & 1 & 27 & 19 \\
\hline \multicolumn{13}{|l|}{ Szatmár- } \\
\hline \multicolumn{13}{|l|}{ Bereg } \\
\hline Bács- & 68 & 7 & 9 & 14 & 3402 & 1 & 3 & 2 & 27182 & 2 & 28 & 26 \\
\hline \multicolumn{13}{|l|}{ Kiskun } \\
\hline Borsod- & 53 & 10 & 30 & 3 & 1209 & 9 & 6 & 1 & 11887 & 7 & 47 & 30 \\
\hline \multicolumn{13}{|l|}{ Abaúj- } \\
\hline \multicolumn{13}{|l|}{ Zemplén } \\
\hline Hajdú- & 72 & 6 & 5 & 17 & 2988 & 2 & 3 & 2 & 20676 & 3 & 30 & 30 \\
\hline \multicolumn{13}{|l|}{ Bihar } \\
\hline Csongrád- & 37 & 13 & 36 & 1 & 1709 & 6 & 1 & 11 & 15754 & 5 & 35 & 36 \\
\hline \multicolumn{13}{|l|}{ Csanád } \\
\hline Pest & 84 & 5 & 28 & 4 & 1702 & 7 & 0 & 16 & 14128 & 6 & 31 & 38 \\
\hline Békés & 26 & 19 & 19 & 7 & 2420 & 3 & 1 & 11 & 16124 & 4 & 47 & 44 \\
\hline Tolna & 64 & 8 & 11 & 11 & 1187 & 10 & 2 & 5 & 7307 & 14 & 48 & 48 \\
\hline Győr- & 153 & 1 & 10 & 13 & 1180 & 11 & 1 & 11 & 7109 & 15 & 47 & 51 \\
\hline \multicolumn{13}{|l|}{ Moson- } \\
\hline \multicolumn{13}{|l|}{ Sopron } \\
\hline Veszprém & 47 & 11 & 25 & 5 & 538 & 17 & 3 & 2 & 5416 & 17 & 57 & 52 \\
\hline Jász- & 32 & 17 & 5 & 17 & 1836 & 5 & 2 & 5 & 11167 & 9 & 33 & 53 \\
\hline \multicolumn{13}{|l|}{ Nagykun- } \\
\hline \multicolumn{13}{|l|}{ Szolnok } \\
\hline Budapest & 93 & 2 & 36 & 1 & 578 & 16 & 0 & 16 & 735 & 20 & 72 & 55 \\
\hline Fejér & 36 & 15 & 12 & 9 & 1393 & 8 & 1 & 11 & 7118 & 12 & 66 & 55 \\
\hline Somogy & 47 & 11 & 14 & 8 & 1034 & 12 & 0 & 16 & 11821 & 8 & 60 & 55 \\
\hline Zala & 37 & 13 & 7 & 15 & 639 & 15 & 2 & 5 & 9040 & 10 & 52 & 58 \\
\hline Baranya & 91 & 4 & 4 & 19 & 997 & 14 & 1 & 11 & 7334 & 13 & 59 & 61 \\
\hline Komárom- & 33 & 16 & 12 & 9 & 497 & 19 & 2 & 5 & 3660 & 19 & 84 & 68 \\
\hline \multicolumn{13}{|l|}{ Esztergom } \\
\hline Heves & 21 & 20 & 11 & 11 & 1014 & 13 & 0 & 16 & 8095 & 11 & 52 & 71 \\
\hline Vas & 27 & 18 & 7 & 15 & 529 & 18 & 2 & 5 & 5761 & 16 & 62 & 72 \\
\hline Nógrád & 54 & 9 & 3 & 20 & 292 & 20 & 0 & 16 & 3867 & 18 & 72 & 83 \\
\hline Összesen & 1167 & & 304 & & 27389 & & 32 & & 221777 & & & \\
\hline
\end{tabular}

Forrás: Benedek, Balázs (2014) és 2019. évi saját adatgyüjtés alapján a szerző szerkesztése ÉRTI ${ }_{j}$ 2019b: módosított indikátorral számolt érték 2019-es adatokkal 
1. ábra: A helyi élelmiszerrendszer szereplőinek megyei aktivitási szintje (ÉRTI $) 2014$ Level of activity of local food system stakeholders on a county basis (ÉRTI $) 2014$

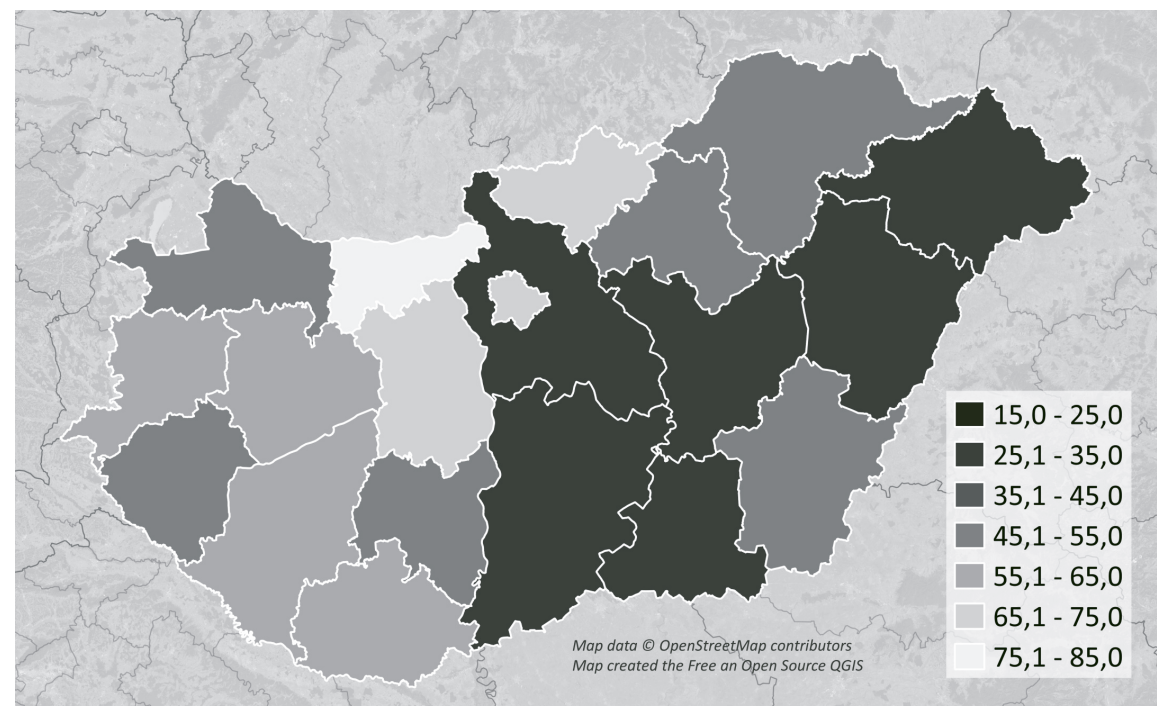

Forrás: Benedek, Balázs (2014) alapján a szerző szerkesztése

2. ábra: A helyi élelmiszerrendszer szereplőinek megyei aktivitási szintje (ÉRTI $) 2019$ Level of activity of local food system stakeholders on a county basis (ÉRTI $) 2019$

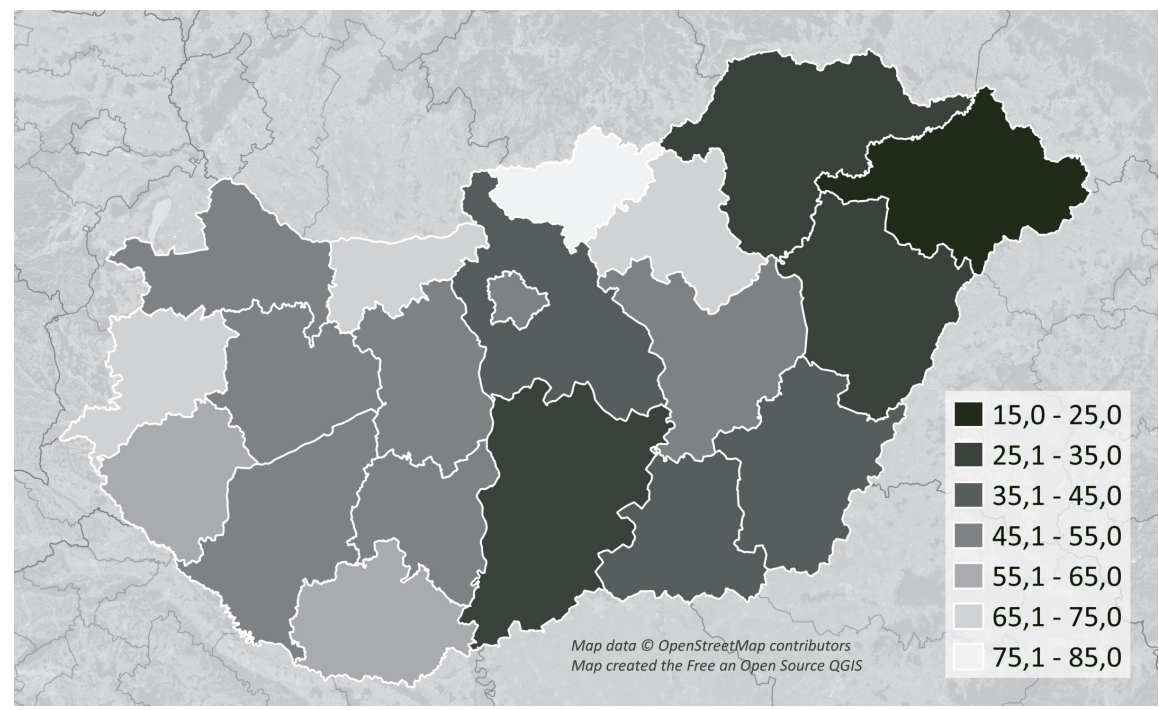

Forrás: Saját adatgyüjtés alapján a szerző szerkesztése 
akár meg is előzi. A leszakadó Nógrád megye helyzete még inkább romlott, így itt még nagyobb erőfeszítések szükségesek a kistermelői aktivitási szint növelésére. Összefoglalva elmondható, hogy az elmúlt öt évben ugyan jelentős fejlődés ment végbe a helyi élelmiszer-termelésben és -értékesítésben, de ahogy az a továbbiakból kiderül, a lehetőségek még korántsem kiaknázottak teljes mértékben (3. táblázat, 3-4. ábra).

A támogatások optimális allokációja tekintetében a sorrend 2014-hez képest nem változott jelentősen. Az első három helyezett Szabolcs-Szatmár-Bereg, BácsKiskun és Csongrád-Csanád megyék. Tehát a fejlődés üteme még mindig ezen megyékben lenne a leggyorsabb.

A sereghajtók között Nógrád megye szinte mindegyik mutató alapján a legutolsó, habár viszonylag magas a biogazdálkodók aránya, de a bevonható mezőgazdasági területek kiterjedése szerény, ami korlátozza a további fejlődést. Vas megye a középmezőnyből lecsúszott az utolsó előtti helyre, ami föleg a fejlődési potenciál csökkenésére vezethető vissza. Jelentős különbséget mutat az ÉRTI ${ }_{j}$ és ÉRTI ${ }_{p}$ alapján felállított rangsor 9 megyében is, név szerint Budapest, Békés, Borsod-Abaúj-Zemplén, Győr-Moson-Sopron, Hajdú-Bihar, Heves, Komárom-Esztergom, Somogy, Veszprém megyékben. A 2014-es négy (Budapest, Fejér, Jász-Nagykun-Szolnok, Pest) belső ellentmondást felvonultató megyéhez képest ez jelentős változás, amely a támogatások nem megfelelő allokációjára enged következtetni. ÉRTIj és ÉRTIp mutatók között gyenge pozitív korreláció áll fenn (4. táblázat).

3. ábra: A helyi élelmiszerrendszer megyei szintű fejlődési potenciálja (ÉRTI $) 2014$ The development potential of the local food system on a county basis (ÉRTI $\left.I_{p}\right) 2014$

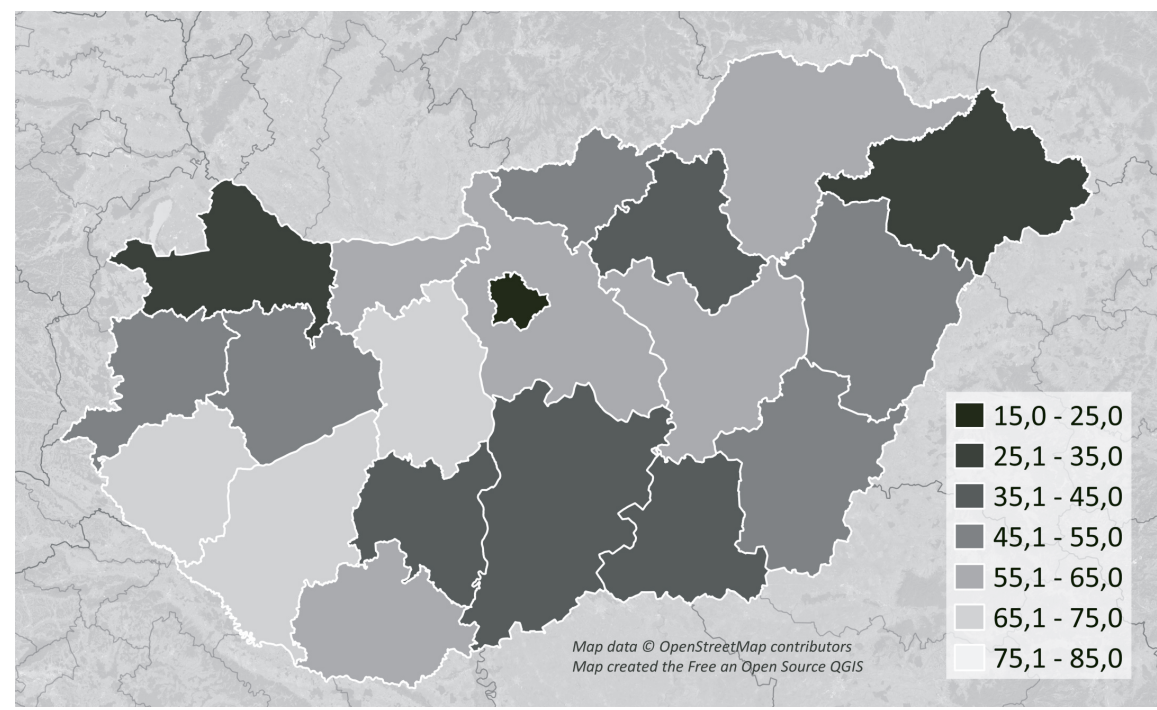

Forrás: Benedek, Balázs (2014) alapján a szerző szerkesztése 
3. táblázat: A helyi élelmiszerrendszer megyei szintű fejlődési potenciálja (ÉRTI $)$ 2014, 2019 The development potential of the local food system on a county basis (ÉRTI $)$ 2014, 2019

Megye/ Biogazdálko- Helyitermelöi Kistermelök A védjegyek Részben vagy ERTIj ERTIj Megnevezés dók piacok egészben $2014 \quad 2019 b$ értékesitésre termelö egyéni gazdaságok

Aránya Rang- Száma Rang- Aránya Rang- Száma Rang- Aránya Rang-

\begin{tabular}{|c|c|c|c|c|c|c|c|c|c|c|c|c|}
\hline & & sor & (db) & sor & & sor & $(\mathrm{db})$ & sor & & sor & & \\
\hline Budapest & 7,27 & 1 & 36 & 1 & 45,19 & 1 & 0 & 16 & 57,47 & 4 & 19 & 23 \\
\hline Győr- & 1,21 & 2 & 10 & 13 & 9,37 & 2 & 1 & 11 & 56,44 & 5 & 34 & 33 \\
\hline \multirow{2}{*}{\multicolumn{13}{|c|}{$\begin{array}{l}\text { Moson- } \\
\text { Sopron }\end{array}$}} \\
\hline & & & & & & & & & & & & \\
\hline Veszprém & 0,42 & 5 & 25 & 5 & 4,77 & 14 & 3 & 2 & 48,07 & 13 & 50 & 39 \\
\hline Bács- & 0,16 & 16 & 9 & 14 & 7,83 & 5 & 3 & 2 & 62,53 & 2 & 37 & 39 \\
\hline \multicolumn{13}{|l|}{ Kiskun } \\
\hline Csongrád- & 0,15 & 17 & 36 & 1 & 7,07 & 9 & 1 & 11 & 65,21 & 1 & 42 & 39 \\
\hline Csanád & & & & & & & & & & & & \\
\hline Szabolcs- & 0,18 & 13 & 20 & 6 & 4,34 & 15 & 2 & 5 & 53,32 & 7 & 31 & 46 \\
\hline \multicolumn{13}{|l|}{ Szatmár- } \\
\hline \multicolumn{13}{|l|}{ Bereg } \\
\hline Hajdú- & 0,18 & 13 & 5 & 17 & 7,58 & 7 & 3 & 2 & 52,47 & 9 & 46 & 48 \\
\hline \multicolumn{13}{|l|}{ Bihar } \\
\hline Békés & 0,09 & 20 & 19 & 7 & 8,02 & 4 & 1 & 11 & 53,42 & 6 & 49 & 48 \\
\hline Komárom- & 0,39 & 6 & 12 & 9 & 5,86 & 12 & 2 & 5 & 43,12 & 17 & 58 & 49 \\
\hline \multicolumn{13}{|l|}{ Esztergom } \\
\hline Jász- & 0,15 & 17 & 5 & 17 & 8,7 & 3 & 2 & 5 & 52,89 & 8 & 61 & 50 \\
\hline \multirow{2}{*}{\multicolumn{13}{|c|}{$\begin{array}{l}\text { Nagykun- } \\
\text { Szolnok }\end{array}$}} \\
\hline & & & & & & & & & & & & \\
\hline Pest & 0,29 & 8 & 28 & 4 & 5,86 & 12 & 0 & 16 & 48,64 & 11 & 59 & 51 \\
\hline Tolna & 0,37 & 7 & 11 & 11 & 6,92 & 10 & 2 & 5 & 42,61 & 18 & 44 & 51 \\
\hline Fejér & 0,20 & 10 & 12 & 9 & 7,7 & 6 & 1 & 11 & 39,37 & 19 & 71 & 55 \\
\hline Heves & 0,15 & 17 & 11 & 11 & 7,48 & 8 & 0 & 16 & 59,69 & 3 & 42 & 55 \\
\hline Borsod- & 0,17 & 15 & 30 & 3 & 3,97 & 18 & 6 & 1 & 39,03 & 20 & 65 & 57 \\
\hline Abaúj- & & & & & & & & & & & & \\
\hline \multicolumn{13}{|l|}{ Zemplén } \\
\hline Baranya & 0,59 & 4 & 4 & 19 & 6,46 & 11 & 1 & 11 & 47,49 & 15 & 57 & 60 \\
\hline Vas & 0,21 & 9 & 7 & 15 & 4,17 & 16 & 2 & 5 & 45,37 & 16 & 54 & 61 \\
\hline Zala & 0,20 & 10 & 7 & 15 & 3,43 & 20 & 2 & 5 & 48,48 & 12 & 66 & 62 \\
\hline Somogy & 0,19 & 12 & 14 & 8 & 4,17 & 16 & 0 & 16 & 47,73 & 14 & 73 & 66 \\
\hline Nógrád & 0,70 & 3 & 3 & 20 & 3,79 & 19 & 0 & 16 & 50,24 & 10 & 53 & 68 \\
\hline Összesen & & & 304 & & & & 32 & & & & & \\
\hline
\end{tabular}

Forrás: Benedek, Balázs (2014) és 2019. évi saját adatgyüjtés alapján a szerző szerkesztése ÉRTI 2 2019b: módosított indikátorral számolt érték 2019-es adatokkal 
4. táblázat: A támogatások optimális allokációja (OA) megyei szinten $(2014,2019)$ Optimal allocation of subsidies (OA) on the county level $(2014,2019)$

Megye / ERTIJ

ERTIP

NMI'A

OA 2014

OA 20196

Megnevezés

\begin{tabular}{|c|c|c|c|c|c|c|c|c|c|c|}
\hline & Érték & $\begin{array}{l}\text { Rang- } \\
\text { sor }\end{array}$ & Érték & $\begin{array}{c}\text { Rang- } \\
\text { sor }\end{array}$ & Érték & $\begin{array}{c}\text { Rang- } \\
\text { sor }\end{array}$ & Érték & $\begin{array}{c}\text { Rang- } \\
\text { sor }\end{array}$ & Érték & $\begin{array}{c}\text { Rang- } \\
\text { sor }\end{array}$ \\
\hline $\begin{array}{c}\text { Szabolcs- } \\
\text { Szatmár- } \\
\text { Bereg }\end{array}$ & 19 & 1 & 46 & 6 & 39,0 & 7 & 93,5 & 1 & 104,0 & 1 \\
\hline $\begin{array}{c}\text { Bács- } \\
\text { Kiskun }\end{array}$ & 26 & 2 & 39 & 3 & 41,7 & 9 & 105,7 & 3 & 106,7 & 2 \\
\hline $\begin{array}{l}\text { Csongrád- } \\
\text { Csanád }\end{array}$ & 36 & 5 & 39 & 3 & 31,7 & 4 & 111,2 & 4 & 106,7 & 2 \\
\hline $\begin{array}{l}\text { Hajdú- } \\
\text { Bihar }\end{array}$ & 30 & 3 & 48 & 7 & 28,8 & 2 & 103,7 & 3 & 106,8 & 4 \\
\hline Békés & 44 & 7 & 48 & 7 & 23,4 & 1 & 119,1 & 5 & 115,4 & 5 \\
\hline $\begin{array}{l}\text { Győr- } \\
\text { Moson- } \\
\text { Sopron }\end{array}$ & 51 & 9 & 33 & 2 & 40,2 & 8 & 119,7 & 6 & 124,2 & 6 \\
\hline Tolna & 48 & 8 & 51 & 11 & 34,8 & 6 & 122,8 & 7 & 133,8 & 7 \\
\hline $\begin{array}{c}\text { Jász- } \\
\text { Nagykun- } \\
\text { Szolnok }\end{array}$ & 53 & 11 & 50 & 10 & 30,8 & 3 & 135,5 & 8 & 133,8 & 7 \\
\hline Pest & 38 & 6 & 51 & 11 & 51,0 & 15 & 136,9 & 9 & 140,0 & 9 \\
\hline $\begin{array}{l}\text { Borsod- } \\
\text { Abaúj- } \\
\text { Zemplén }\end{array}$ & 30 & 3 & 57 & 15 & 56,9 & 16 & 165,9 & 15 & 143,9 & 10 \\
\hline Fejér & 55 & 12 & 55 & 13 & 34,5 & 5 & 175,2 & 16 & 144,5 & 11 \\
\hline Budapest & 55 & 12 & 23 & 1 & 66,7 & 20 & 153,5 & 11 & 144,7 & 12 \\
\hline Veszprém & 52 & 10 & 39 & 3 & 58,4 & 17 & 163,2 & 13 & 149,4 & 13 \\
\hline $\begin{array}{l}\text { Komárom- } \\
\text { Esztergom }\end{array}$ & 68 & 17 & 49 & 9 & 43,7 & 11 & 187,3 & 19 & 160,7 & 14 \\
\hline Baranya & 61 & 16 & 60 & 16 & 42,8 & 10 & 157,1 & 12 & 163,8 & 15 \\
\hline Heves & 71 & 18 & 55 & 13 & 45,4 & 12 & 141,1 & 10 & 171,4 & 16 \\
\hline Somogy & 55 & 12 & 66 & 19 & 50,8 & 14 & 181,8 & 18 & 171,8 & 17 \\
\hline Zala & 58 & 15 & 62 & 18 & 59,1 & 18 & 175,6 & 17 & 179,1 & 18 \\
\hline Vas & 72 & 19 & 61 & 17 & 50,1 & 13 & 164,5 & 14 & 183,1 & 19 \\
\hline Nógrád & 83 & 20 & 68 & 20 & 64,4 & 19 & 189,1 & 20 & 215,4 & 20 \\
\hline Pearson korr & eláció r & rték & & & & & & & & 0,094 \\
\hline Spearman-fe & e rangk & orreláció & & & & & & & & 0,032 \\
\hline
\end{tabular}

Forrás: Benedek, Balázs (2014) és 2019. évi saját adatgyüjtés alapján a szerző szerkesztése OA 2019b: módosított indikátorral számolt érték 2019-es adatokkal 
A nem mezőgazdasági területek arányát (NMT) is vizsgáltam, mint a fejlődés fizikai korlátozó tényezőjét. Az országos átlag 44,7 százalék, melyhez - a 2014-es elemzéshez hasonlóan - Komárom-Esztergom megye értéke közel esik, viszont a kistermelői aktivitás nagyon alacsony szintű, ami mindenképp gátat vethet a gyors és hatékony rövid ellátási lánc fejlesztésének.

4. ábra: A helyi élelmiszerrendszer megyei szintű fejlődési potenciálja (ÉRTI $) 2019$ The development potential of the local food system on a county basis (ÉRTI $) 2019$

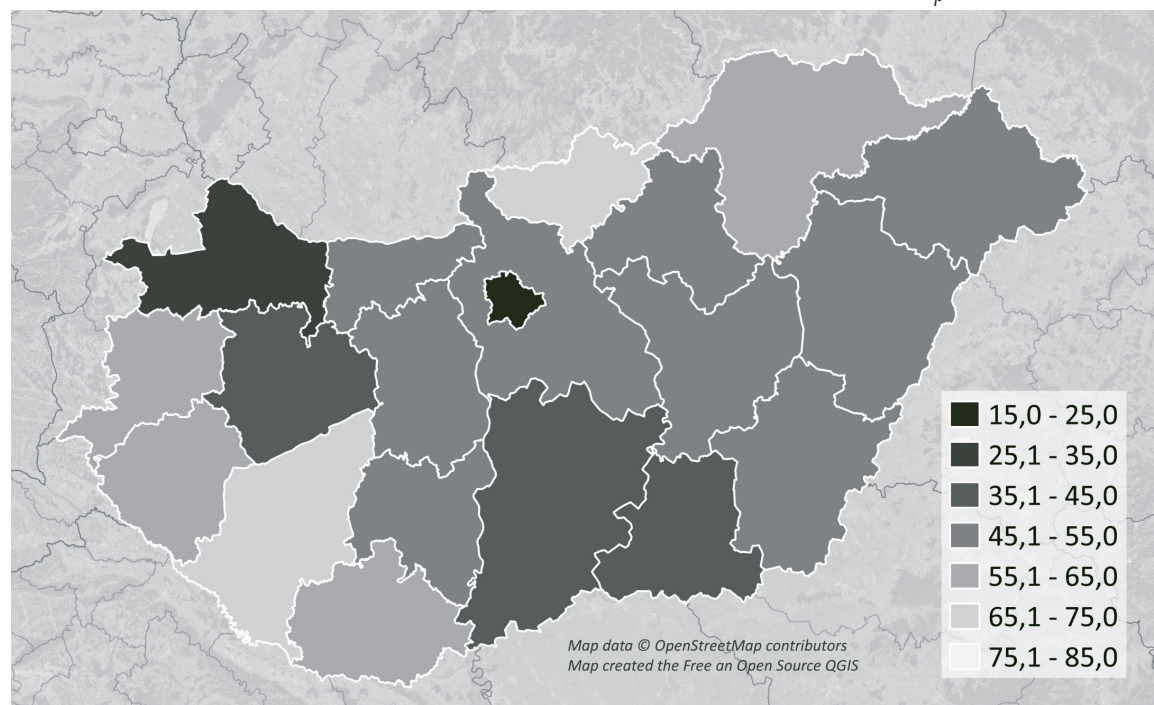

Forrás: Saját adatgyüjtés alapján a szerző szerkesztése

\section{Összefoglalás}

A 2014-ben megjelent közlemény (Benedek, Balázs 2014) adatgyűjtése óta már több, mint öt év eltelt, így időszerű az index újraszámolása, az elért eredmények értékelése. Az elemzés eredeti célja az volt, hogy a 2014-2020-as programozási időszak szakpolitikai döntéshozói számára újszerű módszertani eszközt biztosítson. Ugyan a tanulmány írása idején a programozási időszak még nem zárult le, de az Európai Unió által támogatott fejlesztések már elkezdődtek, illetve számos civil kezdeményezés valósult meg, melyek konkrét források nélkül is biztosíthatják a továbblépést.

A szakirodalmi kutatás és az adatgyüjtés alapján a tanulmány elején két hipotézist fogalmaztam meg. A hipotéziseket az indexszámítás eredményei alapján elemeztem.

H1: A kistermelói aktivitási szint nőtt Magyarországon 2014 és 2019 között.

A hipotézis csak részben igazolható, hiszen a húsz megye közül csak kilencben csökkent ÉRTI értéke, tehát itt nőtt az aktivitás. Két megyében nem vál- 
tozott, míg a többi kilenc megyében csökkent az aktivitási szint. Az ÉRTI jértéke Szabolcs-Szatmár-Bereg (19), Bács-Kiskun (26), majd Hajdú-Bihar (30) és BorsodAbaúj-Zemplén (30) megyékben a legkedvezőbb. Megállapítható, hogy SzabolcsSzatmár-Bereg megyében csökkent leginkább az értéke (27-ről 19-re), Bács-Kiskun megyében szinte alig (28-ról 26-ra), Hajdú-Bihar megyében pedig egyáltalán nem változott az érték (30). Borsod-Abaúj-Zemplén megyében viszont 47-ről 30-ra csökkent, amely jelentős fejlődésnek tekinthető. Ezen megyék még inkább elszakadtak a többiektől. A soron következő Csongrád-Csanád megyében 36, mely csaknem kétszerese az első, Szabolcs-Szatmár-Bereg megye értékének. ÉRTI 2014-ben Komárom-Esztergom megyében volt a legmagasabb, 84. 2019-ben a legmagasabb érték 83 (Nógrád megye). Tehát a kistermelői aktivitás összességében valamelyest növekedett, de az egyes megyék értékeit vizsgálva látható, hogy ez nem minden esetben van így.

H2: A támogatások azokba a megyékbe érkeztek, ahol fel használásuk a leghatékonyabb.

Ha a támogatások optimális allokációja mutatót vizsgáljuk, akkor a 2014-es és 2019-es adatok között nem láthatunk nagy különbségeket a legjobb értékeket felmutató megyék tekintetében. Leghatékonyabbnak a forrásfelhasználás SzabolcsSzatmár-Bereg, Bács-Kiskun, Csongrád-Csanád és Hajdú-Bihar megyékben tekinthető. A jelenlegi helyzetet és a fejlődési potenciált vizsgálva azonban 2014-hez képest romlottak az értékek. A hipotézist cáfolja, hogy jelentős különbséget mutat az ÉRTI ${ }_{j}$ és ÉRTI ${ }_{p}$ alapján felállított rangsor kilenc megyében is: Budapest, Békés, Borsod-Abaúj-Zemplén, Győr-Moson-Sopron, Hajdú-Bihar, Heves, Komárom-Esztergom, Somogy és Veszprém. A 2014-es négy (Budapest, Fejér, Jász-Nagykun-Szolnok, Pest) belső ellentmondást felvonultató megyéhez képest ez jelentős változás, mely arra enged következtetni, hogy a támogatások nem oda érkeznek, ahol felhasználásuk a kistermelői aktivitási szint növelésére a leghatékonyabb lenne. Az eredmények alapján látható, hogy a hagyományosan mezőgazdasági jellegü megyékben hasznosulhatnak leggyorsabban a források. A fizikai korlátozó tényezők és a civil szervezeti, önkormányzati aktivitás az adott megyében meggyorsíthatják a rövid ellátási láncok fejlődését.

Jelen kutatásban, Benedek és Balázs (2014) számításaihoz hasonlóan, elsősorban a termelői oldal került előtérbe. Fontos lenne azonban megvizsgálni a kereslet térbeli elrendeződését is, így kaphatnánk komplex képet a rövid ellátási láncok hazai fejlesztésének térbeli, társadalmi különbségeiről. Látható, hogy a rövid ellátási láncok termelői oldala megyénként eltérő sajátosságokkal rendelkezik, így a szakpolitikai döntésekben szükség lenne arra, hogy a területi tényezőket hangsúlyosabban vegyék figyelembe a regionális, vagy még inkább országos szinten uniformizált támogatásokkal szemben. A területi sajátosságok csak a pontozási szempontok között jelennek meg, ám kevés számú pályázó esetén előfordulhat, hogy az alacsonyabb pontszámmal rendelkező és szakmailag, területi sajátosságok szempontjából kevésbé megalapozott igények is támogatásban részesülnek. A következő programozási időszakban célszerü lenne szak- 
mai szervezetek véleményére is támaszkodva, regionális vagy megyei szinten eltérő tartalmú pályázati felhívások megjelentetése, melyek jobban illeszkednek az adott terület adottságaihoz. A még pontosabb tervezéshez azonban szükséges a fogyasztói szokások és preferenciák, valamint a fizetőképes kereslet területi vizsgálata is.

\section{Köszönetnyilvánítás}

A tanulmány a Magyar Nemzeti Bank Doktori Ösztöndíjpályázat támogatásával készült.

\section{Irodalom}

A magyar mezőgazdaság regionális különbségei, 2016. Agrárium 2016. Gazdaságszerkezeti összeírás. (2016) Központi Statisztikai Hivatal, Budapest

Benedek Zs., Balázs B. (2014): Az élelmiszertermelés relokalizációjának térbeli-társadalmi különbségei Magyarországon. Tér és Társadalom, 4., 63-76. https://doi.org/fr6c

Burton, M. (2001): Consumer attitudes to genetically modified organisms in food in the UK. Eur. Rev. Agric. Econ, 4., 479-498. https://doi.org/bp35hz

Caputo, V., Vassilopoulos, A., Nayga, R. M., Canavari, M. (2013): Welfare effects of food miles labels. J. Consum. Aff. 2., 311-327. https://doi.org/fr6f

Forbes, S. L., Cohen, D. A., Cullen, R., Wratten, S. D., Fountain, J. (2009). Consumer attitudes regarding environmentally sustainable wine: An exploratory study of the New Zealand marketplace. Journal of Cleaner Production, 13., 1195-1199. https://doi.org/b28pgb

Hamza E., Tóth E. (2006): Az egyéni gazdaságok eltartóképessége, megélhetésben betöltött szerepe. Agrárgazdasági tanulmányok 2. AKI, Budapest

Hendrickson, M. K., Heffernan, W. D. (2002): Opening spaces through relocalization: Locating potential resistance in the weaknesses of the global food system. Sociologia Ruralis, 4., 347-369. https:// doi.org/bwtp6x

Hinrichs, C.C. (2003): The practice and politics of food system localization. J. Rural Stud, 1., 33-45. https://doi.org/cnhfhr

Howard, P.H. (2009): Consolidation in the North American organic food processing sector, 1997 to 2007. International Journal of Sociology of Agriculture and Food, 1., 13-30. https://doi.org/fr6j

Ilbery, B. (1984): Core-periphery contrasts in European social well-being. Geography, 69., 289-302.

Ilbery, B., Kneafsey, M., Bamford, M. (2000): Protecting and promoting regional speciality food and drink products in the European Union. Outlook on Agriculture, 1., 31-37. https://doi.org/bq6h6g

Kiss É. (2005): Az Európai Unió a 21. század elején. Akadémiai Kiadó, Budapest

Kneafsey, M., Venn, L., Schmutz, U., Balázs, B., Trenchard, L., Eyden-Wood, T., Sutton, G., Blackett, M., Santini, E. F., Gomez, S. (2013): Short Food Supply Chains and Local Food Systems in the EU. A State of Play of Their Socio-Economic Characteristics. EUR-Scientific and Technical Research Series; Publications Office of the European Union, Luxembourg City, Luxembourg https://doi.org/fr6n

Knox, P. L. (1974): Spatial variations in level of living in England and Wales in 1961. Transactions of the Institute of British Geographers, 7., 1-24. https://doi.org/dszgqt

KSH [Központi Statisztikai Hivatal] (2019): STADAT - 6.4.1.1. Földterület művelési ágak szerint (2000-) (ksh.hu)

Lamine, C. (2015): Sustainability and resilience in agrifood systems: Reconnecting agriculture, food and the environment. Sociol. Rural. 1., 41-61. https://doi.org/gf6v2b 
Marsden, T. (2000): Food matters and the matter of food: Towards a new food governance? Sociol. Rural. 1., 20-29. https://doi.org/bs2jf8

Martinez, S., Hand, M., Pra, M. D., Pollack, S., Ralston, K., Smith, T., Vogel, S., Clark, S., Lohr, L., Low, S., Newman, C. (2010): Local Food Systems Concepts, Impacts, and Issues. USDA-Economic Research Service, Washington, DC, USA

Murdoch, J., Marsden, T., Banks, J. (2000): Quality, nature, and embeddedness: Some theoretical considerations in the context of the food sector. Economic Geography, 76., 107-125. https:// doi.org/fhj82z

Renting, H., Marsden, T.K., Banks, J. (2003): Understanding alternative food networks: exploring the role of short food supply chains in rural development. Environment and planning A 3., 393-412. https://doi.org/dhmh4q

Ricketts Hein, J., Ilbery, B., Kneafsey, M. (2006): Distribution of local food activity in England and Wales: An index of food relocalization. Regional Studies, 3., 289-301. https://doi.org/dgxf6f

Robinson, J. M., Farmer, J. R. (2017): Selling Local. Why Local Food Movements Matter. Indiana University Press, Bloomington https://doi.org/fr6q

Schader, C., Grenz, J., Meier, M. S., Stolze, M. (2014): Scope and precision of sustainability assessment approaches to food systems. Ecol. Soc., 3., https://doi.org/gfkzwk

Smithers, J. Lamarche, J. Joseph, A. E. (2008): Unpacking the terms of engagement with local food at the Farmers' market: Insights from Ontario. Journal of Rural Studies, 3., 337-350. https:// doi.org/bwd3pm

Sonnino, R. (2007): The power of place: Embeddedness and local food systems in Italy and the UK. Anthropology of Food https://doi.org/fr6r

Szabó D. (2017): A termelői piacok piacszervezői, termelői és fogyasztói szempontú vizsgálata. Doktori (Ph.D.) értekezés, Szent István Egyetem, Gazdaság- és Társadalomtudományi Kar, Regionális Gazdaságtani és Vidékfejlesztési Intézet, Enyedi György Regionális Tudományok Doktori Iskola, Gödöllő

Toler, S., Briggeman, B. C., Lusk, J. L., Adams, D. C. (2009): Fairness, farmers markets, and local production. American Journal of Agricultural Economics, 5., 1272-1278. https://doi.org/csxt5z

Van Wezemael, L., Caputo, V., Nayga, R. M., Chryssochoidis, G., Verbeke, W. (2014): European consumer preferences for beef with nutrition and health claims: A multi-country investigation using discrete choice experiments. Food Policy, 44., 167-176. https://doi.org/fr6s

52/2010. (IV. 30.) FVM rendelet a kistermelői élelmiszer-termelés, -eloállítás és -értékesítés feltételeiről

\section{Internetes források}

http://www.inspection.gc.ca/food/labelling/food-labelling-for-industry/origin/local-food-claims/ eng/1368135927256/1368136146333 (Letöltés: 2019. 10. 05.)

https://www.nak.hu/termeloipiac-kereso?view=items (Letöltés: 2019. 09. 14.)

https://www.palyazat.gov.hu/node/56582\# (Letöltés: 2019. 09. 14.) 